magna, nerve injuries, premature epiphyseal fusion, recurrent dislocation, and persistent limp. After such dislocation the overall incidence of abnormality of the hip at skeletal maturity is around $30 \% .^{2-5}$ The incidence of avascular necrosis of the femoral head, which occurs up to two years after injury, is about $10 \% \cdot{ }^{4}$ Factors that predispose to complications are age above 6 years, delay in reduction, severe trauma (usually found in older children), associated fractures, and possibly open reduction. The method of immobilisation after reduction and the length of time beyond four weeks for which the joint is non-weight bearing are not important.

The incidence of complications of traumatic dislocation of the hip in children is thus appreciable though lower than that in adults; however, dislocation occurs with less force. This has an important bearing on mini rugby, in which children as young as 7 or 8 may play. Children may have a tendency to assume the "knee elbow" position on the ground, so leaving them vulnerable to traumatic dislocation of the hip. Our two cases, both sustained in mini rugby, presented to the same orthopaedic surgeon within a short time; this suggests that this injury may be more common than previously thought.

' Mason ML. Traumatic dislocation of the hip in childhood. Report of a case.

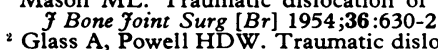

Glass A, Powell HDW. Traumatic dislocation of the hip in children. An analysis of forty-seven patients. $\mathcal{F}$ Bone foint Surg $[B r]$ 1961;43:29-37.

${ }^{3}$ Funk FJ Jr. Traumatic dislocation of the hip in children. Factors influencing prognosis and treatment. F Bone Yoint Surg [Am] 1962;44:1135-45.

ennsylvania Orthopedic Society. Traumatic dislocation of the hip joint in children. Final report of the scientific research committee. F Bone foint Surg $[\mathrm{Am}]$
$1968 ; 50: 79-88$.

$549-53$.

(Accepted 27 April 1984)

Department of Orthopaedic Surgery, Royal Liverpool Hospital, Liverpool L7 8XP

D REES, FRCS, registrar

S K THOMPSON, MCHORTH, FRCS, consultant surgeon

Correspondence to: $\mathrm{Mr} \mathrm{D}$ Rees.

\section{Reversible acute on chronic renal failure during captopril treatment}

Treatment with captopril controls the blood pressure well in most patients with severe hypertension. Nevertheless, some patients may develop reversible renal insufficiency, especially when there is bilateral renal artery stenosis. ${ }^{1}$ We describe three patients with reversible acute on chronic renal failure in the absence of renal artery stenosis.

\section{Case reports}

Case 1-A 51 year old man with a long history of analgesic abuse had been treated for hypertension with clonidine. He had stage 1 hypertensive retinopathy. An ultrasonic tomogram and intravenous urogram with rapid sequence films showed bilateral small kidneys with delayed excretion. There was no evidence of renal artery stenosis. Ten days after starting captopril serum creatinine concentration rose from 380 to $681 \mu \mathrm{mol} / 1$ (43 to $77 \mathrm{mg} / \mathrm{l}$ ) and renal biopsy was performed. Histological examination showed thickening of Bowman's capsule, hyperplastic atherosclerosis of the interlobular arteries, and spontaneous fluorescence of tubular epithelium related to analgesic abuse.

Case 2-A 54 year old man with known hypertension had grade 3 hypertensive retinopathy. There was no suggestion of secondary hypertension. After 11 days of combined treatment with captopril $(75 \mathrm{mg} /$ day) and frusemide $(80 \mathrm{mg} /$ day $)$ serum creatinine concentration rose from $491 \mu \mathrm{mol} / \mathrm{l}$ $(55.5 \mathrm{mg} / \mathrm{l})$ to $673 \mu \mathrm{mol} / 1(76 \mathrm{mg} / \mathrm{l})$. Renal biopsy was performed and examination by light microscopy showed an increase in mesangial matrix and capillary thickening.

Case 3-A 45 year old man had been treated with metoprolol, prasosin, and thiazide. Renal failure was noted before he started taking captopril and an intravenous urogram with rapid sequence films had shown atheromatosis of the aorta and atrophic kidneys, but no evidence of renal artery stenosis. He had stage 3 hypertensive retinopathy. Combined treatment consisted of captopril $25 \mathrm{mg}$, frusemide $80 \mathrm{mg}$, and atenolol $50 \mathrm{mg}$ daily. Serum creatinine concentration rose to $885 \mu \mathrm{mol} / 1(100 \mathrm{mg} / \mathrm{l})$ and haemodialysis was performed on day 11 . A renal biopsy specimen obtained 10 days after starting captopril showed only an increase in mesangial matrix and capillary thickening.

Renal function improved in all three patients with no change in their treatment. Proteinuria was always less than $0.5 \mathrm{~g} / \mathrm{l}$ and no allergic phenomena appeared. Immunofluorescent examination of biopsy specimens did not show significant immune deposits. There was no correlation between changes in blood pressure and those in serum creatinine concentration.

\section{Comment}

In all three patients there was a substantial decline in renal function during the first 10 days of captopril treatment. Hypotension and dehydration did not occur in these patients and there was no evidence of immunological or toxic renal damage induced by captopril.

Severe functional and reversible renal failure has been observed during captopril treatment in patients with bilateral renal artery stenosis or with a solitary kidney with renal artery stenosis. ${ }^{2}$ In such patients renal perfusion pressure is low and angiotensin II is important for maintaining renal blood flow and glomerular filtration. Blocking the converting enzyme in this condition may lead to renal failure. ${ }^{3}$ A similar mechanism could have been responsible for the renal failure in our patients since renal perfusion may be considerably impaired in patients with severe arterial hypertension even without renal artery stenosis. ${ }^{4}$ It is unlikely that diuretics or $\beta$ blockers contribute to this form of reversible renal failure since acute renal failure can occur on captopril alone, and renal function may improve rapidly once captopril is withdrawn even though $\beta$ blockers and diuretics are continued. ${ }^{2}$ In addition, giving diuretics or $\beta$ blockers, or both, to patients on captopril does not adversely affect renal function. ${ }^{1}$

In our patients renal function improved despite continuing captopril treatment. Reversability of captopril induced renal failure has also been noted by Brunner and others in patients who had renal failure before starting captopril. ${ }^{5}$ These cases suggest that in some patients the decline in renal function may be temporary and that stopping the captopril is not always necessary. The improvement in renal

\begin{tabular}{|c|c|c|c|c|c|c|c|}
\hline & $\begin{array}{l}\text { Captopril } \\
\text { daily dose } \\
\text { (mg) }\end{array}$ & $\begin{array}{l}\text { Other drugs taken } \\
\text { during treatment } \\
\text { with captopril } \\
\text { (mg) }\end{array}$ & $\begin{array}{l}\text { Blood pressure } \\
(\mathrm{mm} \mathrm{Hg})\end{array}$ & $\begin{array}{c}\text { Body } \\
\text { weight } \\
(\mathrm{kg})\end{array}$ & $\underset{\substack{\text { Serum } \\
\text { creatinine } \\
(\mu \mathrm{mol} / \mathrm{l})}}{ }$ & $\underset{\substack{\text { Serum } \\
\text { urea } \\
(\mathrm{mmol} / \mathrm{l})}}{\left(\mathrm{m}^{2}\right.}$ & $\begin{array}{l}\text { Plasma renin } \\
\text { activity } \\
\text { (ng/ml/h) }\end{array}$ \\
\hline \multicolumn{8}{|l|}{ Case 1} \\
\hline $\begin{array}{l}\text { Before captopril } \\
\text { At highest creatinine concentration }\end{array}$ & 75 & \multirow{3}{*}{$\begin{array}{l}\text { Atenolol } 100 \\
\text { Frusemide } 40 \\
\text { Atenolol } 100 \\
\text { Frusemide } 40 \\
\text { Atenolol } 100 \\
\text { Frusemide } 40\end{array}$} & $\begin{array}{l}240 / 120 \\
135 / 98\end{array}$ & $\begin{array}{l}56 \cdot 9 \\
55 \cdot 2\end{array}$ & $\begin{array}{l}380 \\
681\end{array}$ & $\begin{array}{l}17 \cdot 5 \\
45 \cdot 3\end{array}$ & \multirow[t]{3}{*}{$2 \cdot 47$} \\
\hline After 3 months' treatment & 75 & & $170 / 100$ & 59.0 & 354 & $20 \cdot 7$ & \\
\hline After 9 months' treatment & 75 & & $170 / 95$ & $66 \cdot 0$ & 283 & $15 \cdot 3$ & \\
\hline $\begin{array}{l}\text { Case } 2 \\
\text { Before captopril } \\
\text { At highest creatinine concentration } \\
\text { After } 3 \text { months' treatment }\end{array}$ & $\begin{array}{r}75 \\
150\end{array}$ & \multirow{2}{*}{$\begin{array}{l}\text { Frusemide } 80 \\
\text { Frusemide } 80 \\
\text { Atenolol } 50 \\
\text { Frusemide } 80 \\
\text { Atenolol } 50\end{array}$} & $\begin{array}{l}210 / 120 \\
150 / 95 \\
160 / 100\end{array}$ & $\begin{array}{l}70 \cdot 7 \\
69.7 \\
69.0\end{array}$ & $\begin{array}{l}491 \\
673 \\
398\end{array}$ & $\begin{array}{l}18 \cdot 8 \\
42 \cdot 3 \\
23 \cdot 3\end{array}$ & \multirow[t]{2}{*}{$3 \cdot 25$} \\
\hline After 9 months' treatment & 150 & & $160 / 100$ & $71 \cdot 7$ & 266 & $16 \cdot 8$ & \\
\hline $\begin{array}{l}\text { Case } 3 \\
\text { Before captopril } \\
\text { At highest creatinine concentration } \\
\text { After } 3 \text { months' treatment }\end{array}$ & $\begin{array}{l}25 \\
12.5\end{array}$ & \multirow{2}{*}{$\begin{array}{l}\text { Frusemide } \\
\text { Atenolol } 50 \\
\text { Frusemide } 80 \\
\text { Atenolol } 50\end{array}$} & $\begin{array}{l}170 / 130 \\
170 / 95 \\
170 / 100\end{array}$ & $\begin{array}{l}47.5 \\
47.7 \\
49.5\end{array}$ & $\begin{array}{l}557 \\
885 \\
504\end{array}$ & $\begin{array}{l}47.8 \\
73 \cdot 0 \\
39.5\end{array}$ & \multirow[t]{2}{*}{$6 \cdot 15$} \\
\hline After 9 months' treatment & 12.5 & & $120 / 80$ & $47 \cdot 5$ & 389 & $24 \cdot 2$ & \\
\hline
\end{tabular}


function during prolonged treatment with captopril suggests that some of the renal impairment observed before treatment might be due to a functional disorder.

We recommend close monitoring of renal function at the start of treatment with captopril in patients with chronic renal failure and severe arterial hypertension.

'Anonymous. Captopril: benefits and risks in severe hypertension [Editorial]. Lancet 1980;ii:129-30.

Coulie P, De Plaen JF, van Ypersele de Strihou C. Captopril induced acute reversible renal failure. Nephron $1983 ; 35: 108-11$.

Blythe WB. Captopril and renal autoregulation N Engl f Med 1983;308:390-1. ollenberg NK, Adams DF. The renal circulation in hypertensive disease. $\mathrm{Am} \mathcal{F}$ Med 1976;60:773-84

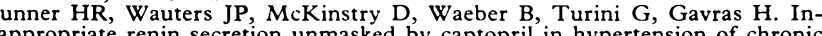
renal failure. Lancet 1978 ;ii:704-7.

Accepted 24 April 1984)

Department of Medicine, Academisch Ziekenhuis-VUB, Laarbeeklaan 101, B-1090 Brussels, Belgium

DIERIK L VERBEELEN, MD, physician

STEFAN DE BOEL, MD, assistant physician

Correspondence to: Dr D L Verbeelen.

\section{Potassium supplements during treatment of glaucoma with acetazolamide}

Drugs that inhibit carbonic anhydrase, such as acetazolamide, lower the pressure in most glaucomatous eyes. The ocular hypotensive effects of the drugs appear to be independent of their diuretic action. ${ }^{1} \mathrm{~A}$ common side effect of treatment with acetazolamide is paraesthesia in the legs and arms. ${ }^{2}$ This is a symptom of hypokalaemia, so patients suffering from this side effect are often given potassium supplements. This study aimed at determining the necessity for potassium supplements.

\section{Patients, methods, and results}

Of a random sample of 150 patients attending hospital ophthalmic clinics and receiving acetazolamide to treat glaucoma, $145(96.9 \%)$ also received potassium supplements. In almost all cases the supplement was one potassium chloride slow release tablet (slow $\mathrm{K} ; 600 \mathrm{mg}(8 \mathrm{mmol})$ ) daily. We ran domly selected 16 patients with glaucoma who had been treated with acetazolamide and potassium supplements for more than three months. They were questioned about their diet, drug compliance, drug history, and unwanted side effects. Any factor in their medical history that might influence their serum potassium concentrations was taken into consideration. Serum potassium and bicarbonate concentrations were measured, and potassium supplements were then withdrawn from all patients. Serum potassium concentrations were measured monthly, and the patients were asked about relevant changes in dietary habits and side effects.

Fifteen patients were taking $8 \mathrm{mmol}(600 \mathrm{mg})$ and one $16 \mathrm{mmol}(1200 \mathrm{mg})$ potassium daily. None had a medical history that might affect their serum potassium concentration. The daily dose of acetazolamide ranged from 500 $\mathrm{mg}$ to $1000 \mathrm{mg}$. Of the patients studied, 15 were white and one Asian; their mean (SD) age was $64 \cdot 3(12 \cdot 1)$ years. The serum bicarbonate concentration was used as an estimate of compliance, as acetazolamide is a carbonic anhydrase inhibitor, and all patients had serum concentrations below the normal limit of $24 \mathrm{mmol}(\mathrm{mEq}) / \mathrm{l}$. They were all also assessed after interview as being good compliers.

The diet of 15 of the 16 patients did not change; the remaining patient received a poor diet throughout the study. The incidence of paraesthesia did not alter after potassium was stopped. but nausea stopped in two patients who had previously suffered from it. The results are summarised in the figure.

Analysis of variance showed that serum potassium concentrations in patients who had stopped taking potassium supplements were not significantly different from those in patients taking potassium or from concentrations in a standard population of a similar age. Two patients who had never taken potassium supplements and had been taking acetazolamide for more than five years were found to have normal potassium concentrations.

\section{Comment}

The diuretic effect of acetazolamide is due to inhibition of carbonic anhydrase in the kidney tubules, which reduces the formation of hydrogen and bicarbonate ions. This increases the volume of urine, and metabolic acidosis follows. Further acidosis does not occur with continued acetazolamide treatment as there is a compensatory increase in reabsorption of bicarbonate in the proximal tubule. An initial loss of potassium occurs, but this is self limiting, as is the diuresis. ${ }^{3}$ Thus hypokalaemia may occur during the first two weeks of treatment with acetazolamide, and during this period potassium supplements may be required. Further work is needed to determine their necessity.

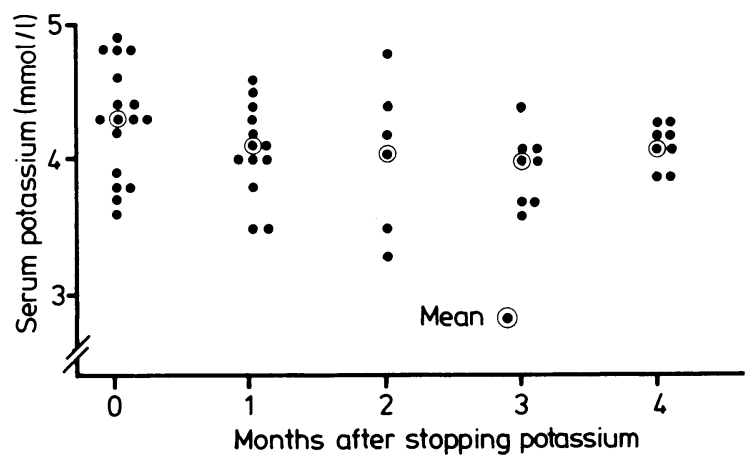

Serum potassium concentrations in patients with glaucoma treated witha cetazolamide after they stopped taking potassium supplements.

Conversion: SI to traditional units-Potassium: $1 \mathrm{mmol} / \mathrm{l}$ $=1 \mathrm{mEq} / \mathrm{l}$.

From the results obtained and the recent reports of the side effects of potassium ${ }^{4}$ it seems logical to recommend potassium supplementation only in patients with proved hypokalaemia. If a supplement is required this should be given in a dose that is sufficient to have a therapeutic effect.

' Maren TH. Effects of Diamox on electrolyte metabolism. Bulletin of the fohns Hopkins Hospital 1954;9:277-32

${ }^{2}$ Epstein DL. Carbonic anhydrase inhibitor side effect, serum chemical analysis. Arch Ophthalmol 1977;95:1378-82.

Ellis PP. Carbonic anhydrase inhibitors: pharmacologic effects and problems of long therapy. Symposia on Ocular Therapy 1960;4:32-8.

McMahon FG. Upper gastrointestinal lesions after potassium chloride supplements; a controlled clinical trial. Lancet 1982;ii:1059-61.

(Accepted 27 April 1984)

Department of Pharmacy, Bolton General Hospital, Bolton BL4 0JR A S CRITCHLOW, BSC, MPS, pharmacist

S F FREEBORN, MSC, MPS, principal pharmacist

Department of Ophthalmology, Bolton Royal Infirmary, Bolton BL1 4QS

R A RODDIE, MB, FRCS, consultant

Correspondence to: $\mathrm{Mr}$ A S Critchlow.

\section{Major ocular trauma: a disturbing trend in field hockey injuries}

Injuries due to blows from sticks in hockey have not been reported as contributing greatly to ocular sports injuries. ${ }^{1}$ We describe three perforating eye injuries seen in the first half of one season.

\section{Case reports}

Case 1-A 13 year old girl was hit in the left eye by the stick of an opponent who prematurely played the ball as she ran past. She suffered immediate loss of vision and was admitted to hospital. Examination under general anaesthesia showed a large horizontal corneoscleral laceration with prolapsing iris and ciliary body. The lens could not be identified. A primary repair was made, but six weeks later total hyphaema was still present and an ultrasound scan showed retinal detachment. Vitrectomy was carried out, but a fibrotic retina disinserted through $270^{\circ}$ proved impossible to replace. At follow up the eye had no perception of light and was becoming phthisical. Unaided distance acuity in the right eye remained normal (6/5).

Case 2-A 14 year old girl sustained a blow to her left eye when she ran into a high follow through stroke of a stick during a tackle. On admission a perforating injury was obvious and she had no perception of light in this eye. At operation a long laceration extended vertically from the cornea well 